\title{
- Dewi Cahyani Puspitasari
}

\section{Wirausaha Muda Membangun Desa: Dinamika Partisipasi Pembangunan Desa}

\begin{abstract}
ABSTRAK
Potret pembangunan desa mengalami perubahan yaitu paska adanya Undang-Undang Desa yang memunculkan visi dan komitmen baru terhadap desa. Harapan baru perubahan pembangunan bagi desa menjadi fokus para pihak termasuk pemuda. Beragam inisiatif pemuda muncul di beberapa wilayah Indonesia yang dapat memberikan kontribusi positif dalam proses perubahan sosial di desa. Kajian ini bertujuan untuk; pertama, mendeskripsikan ragam peran dan kapasitas pemuda dalam proses membangun desa dan; kedua, menganalisis potensi dan kapasitas pemuda dalam membangun jejaring untuk keberlanjutan peran pemuda dalam membangun desa. Tinjauan teoritis pembangunan desa, kewirausahaan dan partisipasi pemuda menjadi bagian pembahasan analitis dari kajian ini. Hasil kajian menunjukkan bahwa para wirausaha muda desa ini memiliki kesediaan untuk menjadi bagian dari solusi terhadap permasalahan sosial seperti kemiskinan, minimnya tenaga kerja pertanian maupun rendahnya kualitas pelayanan sosial di desa. Kapasitas pemuda dalam memobilisasi elemen masyarakat desa menjadi bagian penting dalam proses menggerakkan partisipasi warga untuk membangun desa. Implikasinya adalah adanya nilai tambah bagi desa yang muncul dari kemampuan kolektif untuk mendayagunakan potensi maupun aset lokal di desa.
\end{abstract}

Kata kunci: pemuda, wirausaha, pembangunan desa, partisipasi.

\begin{abstract}
The portrait of rural development has experienced a change following the issue of Rural Regulation that has emerged a new vision and commitment to village. A new hope of change in development for the village becomes the concern for any parties including the youth. Many various initiatives emerge in some parts of Indonesia regions that can give a positive contribution in the process of social change in village. This study aims to: First, to describe the roles and capacities of the youth in the process of developing the village and second to analyze the potency and the capacities of the youth in building the network for the continuance of the youth role in developing the village. Theoretical review on the rural development, entrepreneurship and participation of the youth become the parts of analytical discussion of this study. The result of the study showed that the young entrepreneurs in village have a willingness to be a part of solution in social issues such as poverty, minimum agricultural labors and the low level of quality is social service in village. The youth capacity in mobilizing the elements of rural community becomes an important part in the process of mobilizing the people participation to build the village. Its implication is the added value for the village emerged from the collective capability to utilize the potency and local assets in village.
\end{abstract}

Keywords: youth,entrepreneur,rural development,participation. 


\section{PENDAHULUAN}

Pembangunan desa dalam konteks kekinian menunjukkan arah pada kemandirian masyarakat. Pendapat dari Agusta, dkk. (2014) memberi poin penting bahwa kemandirian masyarakat dipandang sebagai suatu kondisi yang terbentuk melalui perilaku kolektif masyarakat melakukan perubahan sosial. Perubahan perilaku kolektif itu dapat didukung melalui program intervensi masyarakat yang dikembangkan oleh pihak luar (pemerintah) yang mensyaratkan adanya gerakan partisipasi masyarakat. Selain itu dapat juga muncul atas dasar inisiatif dan kreativitas masyarakat setempat. Salah satu kajian terdahulu yang menunjukkan perlunya memasukkan unsur pemuda dalam pembangunan desa dilakukan oleh Kartika (2013) yaitu potensi kaum muda di desa dapat dioptimalkan melalui kewirausahaan sesuai minat dan bakat pemuda serta potensi daerah. Penelitian tersebut menunjukkan pentingnya peran pemuda dalam mengembangkan program pembangunan perdesaan yang dirintis secara berkelanjutan oleh pemuda maupun organisasi pemuda. Dari kedua pernyataan tersebut menunjukkan bahwa pemuda sebagai salah satu elemen masyarakat desa memiliki peluang sama dalam peran pembangunan untuk kemajuan dan pengembangan desa.

Dalam konteks pembangunan desa, pemuda menempati posisi sentral dalam dinamika perjalanan perkembangan desa termasuk menjadi bagian dari agen yang secara kreatif dan inovatif mampu memanfaatkan berbagai macam peluang ekonomi yang kemudian mereka dikenal sebagai wirausaha muda. Konsep kewirausahaan senantiasa mengalami perkembangan yaitu tidak hanya membahas aspek mentalitas, kreativitas dan inovasi tetapi mengalami perubahan paradigma untuk merespon kemajuan perubahan dan adaptasi terhadap lingkungan (Puspitasari, 2016). Bila mencermati lebih lanjut, saat ini untuk wilayah desa, gerakan untuk menumbuhkan dan mengembangkan kewirausahaan desa dilakukan oleh pemuda. Kapasitas pengetahuan, semangat serta daya juang yang dimiliki oleh pemuda ini menjadi 'daya ungkit' untuk mengoptimalkan berkah sumber daya alam maupun sumber daya lainnya yang ada di wilayah perdesaan. Kondisi ini selaras dengan momentum perubahan paradigma pembangunan desa paska implementasi Undang-Undang Desa Tahun 2014 yang mendorong prakarsa, gerakan dan partisipasi masyarakat desa untuk pengembangan potensi dan aset desa bagi kesejahteraan masyarakat desa. Dengan demikian, pemuda menjadi modal penting dalam proses dan pengawalan pembangunan desa secara jangka panjang.

Pengembangan kewirausahaan di desa ini menjadi salah satu bentuk peningkatan nilai tambah bagi desa untuk menuju innovation driven economy sesuai dengan visi pembangunan 2025 yang diwujudkan melalui 3 (tiga) hal yaitu: (1) peningkatan nilai tambah dan perluasan rantai nilai proses produksi serta distribusi dari pengelolaan aset dan akses (potensi) sumber daya alam (SDA), geografis wilayah dan sumber daya manusia (SDM) melalui penciptaan kegiatan ekonomi yang terintegrasi dan sinergis di dalam maupun antarkawasan pusat-pusat pertumbuhan ekonomi, (2) mendorong terwujudnya peningkatan efisiensi produksi dan pemasaran serta integrasi pasar domestik 
dalam rangka penguatan daya saing dan daya tahan perekonomian nasional, dan (3) mendorong penguatan sistem inovasi nasional di sisi produksi, proses maupun pemasaran untuk penguatan daya saing global yang berkelanjutan (Kartika (2013). Pernyataan tersebut menunjukkan adanya peluang bagi desa untuk 'membangun Indonesia'. Perspektif baru pembangunan desa menjadi alternatif baru bagi desa untuk menempatkan warga desa termasuk pemuda sebagai subyek dalam pembangunan desa yang berupaya membawa cita-cita kesejahteraan bersama dan berkelanjutan di masa mendatang.

Karena itu kajian ini hadir untuk mengisi diskusi tentang peran strategis dari pemuda khususnya wirausaha muda desa yang dalam kurun waktu terakhir menunjukkan perkembangan di beberapa wilayah Indonesia. Kajian ini bertujuan untuk mengidentifikasi; pertama, peran dan kapasitas pemuda dalam proses membangun desa dan; kedua, menganalisis potensi dan kapasitas pemuda dalam membangun jejaring untuk keberlanjutan peran pemuda dalam membangun desa. Tinjauan pembangunan desa, kewirausahaan dan partisipasi digunakan untuk melakukan analisis dan pembahasan tentang aktualisasi peran pemuda terkait ide dan gagasan kreatif mereka dalam mendorong percepatan pembangunan di desa. Dalam mencermati bentuk kontribusi wirausaha muda desa ini, penulis mengambil contoh aktor muda desa yang ada di wilayah Gunungkidul, Yogyakarta yaitu Sugeng Handoko, penggerak Desa Wisata Nglanggeran (Gunung Api Purba) dan Nur Agis Aulia, pendiri Gerakan Banten Bangun Desa. Karakteristik unik dari pribadi kedua contoh wirausaha muda ini menjadi inspirasi bagi pemuda Indonesia lainnya khususnya dalam hal menginisiasi gerakan pembaharuan masyarakat desa dengan pendekatan kewirausahaan. Metode penulisan dilakukan dengan analisis dekriptif-analitis yaitu menganalisis secara komprehensif data sekunder dan dokumentasi yang relevan dengan pembahasan.

\section{MENEMUKAN POTENSI, MEMOBILISASI ASET DESA}

Kondisi wilayah perdesaan yang ada di Indonesia memiliki beragam karakteristik sosial ekonomi dan tingkat perkembangannya. Secara umum dalam perumusan kebijakan pembangunan, desa dapat dikelompokkan menjadi 3 (tiga) yaitu desa cepat berkembang, desa potensial berkembang dan desa tertinggal. Desa cepat berkembang kebanyakan adalah desa yang dekat dengan atau mempunyai akses yang mudah ke kota. Kegiatan ekonomi masyarakatnya sudah mulai berorientasi pada ekonomi pasar dan menunjukkan perubahan dalam adat dan kebudayaannya. Sementara kelompok desa potensial berkembang, kegiatan ekonomi masyarakatnya ada di sektor primer yaitu pertanian dan pertambangan dengan ciri homogen dalam hal adat dan kebudayaannya. Untuk kelompok desa ketiga yaitu desa yang mempunyai masalah atau keterbatasan tertentu seperti sumberdaya maupun lainnya sehingga menyebabkan kemiskinan desa Rustiadi dan Sugimin (2007). Dari pernyataan tersebut, kedua wilayah yang menjadi kajian ada pada kondisi desa dengan keterbatasan dan masalah sosial. Untuk masyarakat wilayah Desa Nglanggeran, Gunungkidul ada pada kondisi miskin. Sementara desa-desa yang ada dalam pendampingan Gerakan Banten Bangun Desa ada pada kondisi kemiskinan dan pengangguran. Kesamaan permasalahan 
sosial yang dihadapi di kedua wilayah tersebut mendorong aksi peduli dari unsur pemuda yaitu Sugeng Handoko (Nglanggeran, Yogyakarta) dan Nur Agis Aulia (Serang, Banten) untuk menjadi bagian dari solusi permasalahan sosial di wilayah desanya.

Kiprah dan peran strategis dari Sugeng Handoko dan para pemuda Nglanggeran mampu melakukan serangkaian aktivitas yang sinergis dengan para pihak yaitu dengan adanya pelibatan semua unsur sumber daya lokal baik fisik maupun non fisik menjadi sebuah jalan bagi pemecahan masalah penuntasan kemiskinan yang selama ini terkadang belum optimal terjawab melalui program pemerintah. Selain itu adanya kemampuan inovasi dari pemuda yang difokuskan pada peran otonomi institusi lokal untuk mempromosikan transfer pengetahuan dan teknologi untuk memelihara keberlanjutan organisasi wisata. Gagasan tersebut dapat memberikan peluang bagi masyarakat Desa Nglanggeran dalam membuka akses dan ruang partisipasi pemuda dan masyarakat dalam pembangunan desa khususnya pengelolaan desa wisata. Dengan menciptakan konsep pasar bagi kegiatan kepariwisataan di Desa Nglanggeran, lambat laun tingkat kesejahteraan penduduk di sektor ekonomi telah mengalami kenaikan. Penduduk Nglanggeran yang dahulu hanya bisa bekerja di sektor pertanian setelah adanya inisiatif pemuda dapat bekerja sebagai penyedia jasa layanan wisata (Puspitasari,2016). Sementara dalam konteks wilayah Banten, adanya unsur penggerak usaha pertanian, peternakan dan perikanan yang dipelopori oleh Nur Agis Aulia melalui gerakan Banten Bangun Desa (BBD) menjadi bagian penting proses identifikasi aset dan potensi desa.
Kegiatan BBD ini dilakukan di Desa Sambilawang, Kecamatan Waringin Kurung, Kabupaten Serang. Dari profil BBD (2016) dijelaskan tentang kontribusi komunitas bagi desa di Banten khususnya dari sektor pertanian, perkebunan, peternakan, perikanan, dan kelautan. Komunitas BBD juga berusaha melahirkan agropreneur muda yang handal dan berakhlak yang siap membangun desa, melalui program-program pelatihan, kunjungan serta program pengembangan diri lainnya. Gambaran profil tersebut memberikan pemahaman bahwa aktor muda desa melakukan serangkaian aktivitas yang mengarah pada pengidentifikasian potensi desa. Hal ini dilakukan untuk dapat memberikan gambaran bagi pelaku perubahan (gerakan) untuk mengetahui kuantitas aset berdasarkan kepemilikan, pemanfaatan dan kondisinya. Dengan dasar inilah kemudian mampu menyusun rencana sistematis untuk memobilisasi sumber daya manusia, sumber daya teknologi dan modal yang ada di desa.

Gambaran inisiatif dari kedua pemuda di atas menunjukkan adanya karakteristik wirausaha. Karakter mendasar dari seorang wirausaha (entrepreneur) menurut Asy'arie (2016) adalah karakter kuat dalam menghadapi tantangan perubahan yang terjadi dalam hidupnya. Seseorang yang tidak akan pernah mundur jika belum tercapai cita-citanya. Tantangan baru bisa diterima dan dinikmati oleh seorang wirausaha. Kesediaan untuk mengenerasi dirinya sendiri adalah sebuah kearifan untuk tidak bergantung pada bantuan orang lain. Bila menemui kerugian dimaknai sebagai jalan untuk keuntungan, seperti umpan dalam kail yang diberikan untuk dimakan ikan yang akan dipancing. Dengan kata lain, sikap positif dimunculkan oleh wirausaha sebagai bagian yang harus 
dilaluinya untuk mendapat sukses dan kebangkitan kembali. Selain itu juga adanya unsur kreatifitas yang merupakan bagian penting lainnya dari seorang wirausaha yang dapat melahirkan inovasi yang diperlukan dalam menghadapi persaingan dan perubahan zaman. Kreatifitas kewirausahaan ini dapat diwujudkan melalui kemampuan membangun jejaring (networking) yang bagus sehingga memungkinkan untuk memberikan dukungan terhadap usahanya. Dengan berjejaring ini maka keterbatasan seorang wirausaha dapat diatasi dan akan lebih mempercepat dan memperluas usahanya.

Bila ditinjau dari konsep kewirausahaan, salah satu pendekatan yang digunakan dalam kajian ini adalah pendekatan proses dari kewirausahaan yang dikenal dengan pendekatan integratif (integrative approach) oleh Michael $\mathrm{H}$. Morris, Pamela S. Lewis dan Donald L. Sexton (dalam Kuratko, 2014) yaitu adanya konsep input dalam proses kewirausahaan yang kemudian menghasilkan outcome. Berikut skema modelnya:

\section{Gambar 1. Model Integratif Kewirausahaan}

\begin{tabular}{l|l|} 
Environmental \\
opportunities
\end{tabular}

Sumber: Kuratko, Donald (2014).

Berdasarkan Gambar I dapat dijelaskan tentang fenomena kedua wirausaha muda desa yang menjadi contoh kasus kajian ini. Dari sisi input dapat dijelaskan tentang: (1) peluang lingkungan, kedua wilayah perdesaan memiliki kondisi awal berupa kemiskinan dan pengangguran yang mendorong kedua pemuda Sugeng Handoko dan Nur Agis Aulia melakukan optimalisasi potensi sumber daya alam dan sumber daya manusia desa, (2) karakter individu dari kedua pemuda yang pantang menyerah dan berani tampil beda diantara potret pemuda desa lainnya melengkapi langkah mereka dalam melakukan perubahan sosial ekonomi desa, (3) konteks organisasi seperti Karang Taruna maupun Kelompok Tani yang menjadi media konsolidasi kedua inisiator muda dalam melakukan pelembagaan aktivitas perubahan sosial desa, (4) keunikan bisnis konsep yang dimunculkan oleh pemuda yaitu mereka memiliki gagasan inovatif dalam menciptakan nilai bisnis yang tidak hanya berorientasi profit tetapi juga menjawab permasalahan sosial desa, dan 
(5) sumber daya, kemampuan kedua pemuda dalam mengidentifikasi,memobilisasi dan meningkatkan kapasitas maupun produktifitas sumber daya desa menjadi bagian penting untuk implementasi ide/gagasan bisnis. Dari kelima input tersebut kemudian berproses sesuai tingkat intensitas implementasi kewirausahaan yang dioperasionalkan oleh kedua pemuda. Aspek inovasi, kesediaan mengambil risiko dan proaktif baik secara bisnis maupun sosial menjadi bagian penting yang menentukan keberlanjutan hasil (outcomes) dari kewirausahaan yang ada. Ragam hasil (outcomes) berupa aktivitas bisnis (usaha), nilai dan manfaat dari usaha baik produk maupun jasa dengan dukungan teknologi mampu meningkatkan pertumbuhan pendapatan dan aset termasuk membuka kesempatan kerja.

\section{MENGGERAKKAN PARTISIPASI, MENGALIRKAN MANFAAT BAGI DESA}

Belajar dari pengalaman pemuda dalam memobilisasi sumber daya lokal desa baik yang dilakukan oleh Sugeng Handoko (Gunungkidul, Yogyakarta) dan Nur Agis Aulia (Banten) menunjukkan usaha pemutusan mata rantai kemiskinan di desa. Pengembangan usaha ekonomi lokal berupa pertanian, peternakan dan pariwisata menjadi bentuk aksi nyata para pemuda ini dengan melibatkan elemen masyarakat desa baik pemerintah desa sampai rumah tangga. Konsep para pemuda ini untuk menggerakkan warga desa merupakan peran inovatif yang mampu memberdayakan dirinya sebagai subjek pembangunan di wilayahnya. Kapasitas para pemuda dalam mengembangkan unitunit usaha komunitas warga, melakukan penguatan kapasitas kelembagaan pemuda desa salah satunya Karang Taruna ini mewujudkan suatu bentuk tata kelola sumber daya desa. Pada akhirnya pemuda ini mampu menumbuhkan kembali warga desa khususnya pemuda desa sebagai subjek yang memiliki kebanggan terhadap desanya.

Pembahasan tersebut sesuai dengan konsep partisipasi masyarakat, salah satunya dapat mengacu pendapat Mikkelsen (Rukminto, 2008) yaitu:

1. Partisipasi adalah kontribusi sukarela dari masyarakat dalam suatu proyek (pembangunan), tetapi tanpa mereka ikut terlibat dalam pengambilan keputusan;

2. Partisipasi adalah proses membuat masyarakat menjadi lebih peka dalam rangka menerima dan merespon berbagai proyek pembangunan;

3. Partisipasi adalah suatu proses aktif yang bermakna bahwa orang ataupun kelompok yang sedang ditanyakan mengambil inisiatif dan mempunyai otonomi untuk melakukan hal itu;

4. Partisipasi adalah proses menjembatani dialog antara komunitas lokal dan pihak penyelenggara proyek dalam rangka persiapan, pengimplementasian, pemantauan dan pengevaluasian staf agar dapat memperoleh informasi tentang konteks sosial ataupun dampak sosial proyek terhadap masyarakat;

5. Partisipasi adalah keterlibatan masyarakat secara sukarela dalam perubahan yang ditentukan sendiri oleh masyarakat;

6. Partisipasi adalah keterlibatan masyarakat dalam upaya pembangunan lingkungan, kehidupan dan diri mereka sendiri.

Dari penjelasan sebelumnya menunjukkan bahwa dimensi partisipasi ada pada motif sukarela, adanya kepekaan dan adaptasi 
secara aktif untuk memunculkan komunikasi antar para pihak yang terlibat dalam aktivitas pelibatan masyarakat. Pengalaman praktik yang dilakukan oleh kedua wirausaha muda dalam kajian ini menunjukkan adanya upaya memobilisasi partisipasi elemen masyarakat desa melalui komunitas sosial warga maupun kelembagaan desa. Selain itu terdapat usaha untuk menumbuhkan kesadaran bersama dalam melakukan aktivitas membangun desa dengan menjalin komunikasi, koordinasi dan berjejaring antara aktor pemuda dengan aktor komunitas sosial maupun kelembagaan desa tersebut.

Keberadaan wirausaha muda desa memiliki kontribusi dalam memberikan manfaat keberlanjutan baik bagi subjek pemuda, keluarga, komunitas, kelembagaan sosial dan masyarakat desa secara luas. Hal ini dapat diilustrasikan dari sumber dokumentasi sejarah pengelolaan di Desa Nglanggeran (Puspitasari, 2016) terjadi dinamika dalam pengelolaan wisata. Bila ditinjau dari tahun sebelum 2007 terjadi stagnasi/vakumnya pengelolaan saat setelah terjadi gempa 26 Mei 2006 hingga tahun 2007. Keberadaan organisasi pemuda yaitu karang taruna pada tahun 2007 mulai muncul untuk melakukan pengelolaan kawasan wisata dengan pendampingan dari Dinas Kebudayaan dan Pariwisata (Budpar) Kabupaten Gunungkidul. Selain itu adanya sebuah lembaga Badan Pengelola Desa Wisata (BPDW) yang melibatkan seluruh komponen masyarakat dari anggota PKK, kelompok tani, pemerintah desa serta pemuda karang taruna. Setelah terbentuk BPDW disepakati dan ditetapkan untuk pengelola teknis lapangan adalah pemudapemudi karang taruna selaku pengelola Kawasan Ekowisata Gunung Api Purba. Dengan mendapatkan beberapa pelatihan dari Dinas Budpar Gunungkidul dan Dinas
Pariwisata DIY serta adanya beberapa pengurus yang menempuh pendidikan di perguruan tinggi yang mendukung perkembangan wisata secara signifikan di Desa Nglanggeran (Puspitasari, 2016).

$$
\text { Dalam upaya memastikan }
$$

keberlanjutan dari manfaat inisiasi usaha ekonomi rintisan wirausaha muda, pendapat dari wirausaha muda desa, Nur Agis Aulia (2014) adalah membentuk kemandirian atau inisiatif masyarakat dalam mengelola program pemberdayaan yang muncul dari aktivitas ekonomi masyarakat. Membangun sebuah kelompok/institusi/lembaga tidak hanya untuk keperluan administrative semata, melainkan untuk menjawab kebutuhan dan memberikan kemanfaatan yang cukup besar untuk mengatasi problem sosial masyarakat dan menciptakan kesejahteraan. Pernyataan tersebut menjadi menarik untuk dikaji dari konsep partisipasi yang menjadi krusial dalam proses pembangunan desa. Kesediaan untuk saling berbagi peran, melembagakan nilai kerjasama sehingga dapat memobilisasi partisipasi warga desa untuk memunculkan kegiatan ekonomi yang memberi kesejahteraan berkelanjutan bagi desa secara keseluruhan.

\section{MERAWAT JEJARING UNTUK KEBERLANJUTAN \\ KESEJAHTERAAN DESA}

Dalam pembangunan masyarakat desa secara teoretis dapat dikategorikan menjadi tiga macam pendekatan pembangunan yaitu mobilisasi, partisipatif dan akulturasi. Pada pendekatan mobilisasi, masyarakat yang menjadi sasaran tidak memiliki andil apapun dalam merencanakan pembangunan yang dilakukan, sementara pada pendekatan partisipatif antara perencana (agents) 
pembangunan secara bersama-sama merancang dan memikirkan pembangunan yang dilakukan oleh masyarakat. Dalam pendekatan akulturatif, masyarakat sasaran dibebaskan untuk memilih yaitu apakah ikut terlibat dengan program yang dirancang mereka atau tidak (Suharto,2016). Adanya pendapat tersebut menunjukkan bahwa pembangunan desa pada hakikatnya adalah segala bentuk aktivitas manusia (masyarakat dan pemerintah) di desa dalam membangun diri, keluarga, masyarakat dan lingkungan di wilayah desa baik yang bersifat fisik, ekonomi, sosial, budaya, politik, ketertiban, pertahanan dan keamanan, agama dan pemerintahan yang dilakukan secara terencana dan membawa dampak positif terhadap kemajuan desa. Kolaborasi antar pihak dalam hal ini negara (pemerintah) dengan unsur masyarakat sipil menjadi penting dalam melakukan beragam stimulan kegiatan untuk percepatan pembangunan desa di berbagai aspek kehidupan masyarakat. Dengan demikian, pembangunan desa sesungguhnya merupakan upaya-upaya sadar dari masyarakat dan pemerintah baik dengan menggunakan sumberdaya yang bersumber dari desa, bantuan pemerintah maupun bantuan organisasi-organisasi/lembaga domestik maupun internasional untuk menciptakan perubahan-perubahan ke arah yang lebih baik.

Aspek penting dari proses pembangunan desa melalui kelembagaan desa salah satunya berkaitan dengan konsep partisipasi adalah jejaring antar kelembagaan. Dalam masyarakat terdapat berbagai bentuk kelembagaan, baik yang terbentuk karena struktur adat, kesatuan wilayah, kesatuan primordial, kesamaan minat maupun kepentingan. Aktivitas para pemuda dalam contoh kasus kajian ini menunjukkan adanya upaya pengembangan masyarakat yang merupakan bagian dari pembangunan sosial. Dalam hal ini, secara konsep menjadi penting untuk memahami karakteristik dari komponen pengelola pengembangan masyarakat sehingga memiliki hubungan kerjasama yang erat dalam memberikan gagasan, ide, perhatian, dukungan, pendampingan yang saling melengkapi. Berikut ilustrasinya:

\section{Gambar 2. Keterkaitan Hubungan antar Komponen Inti Pengelola Pengembangan}

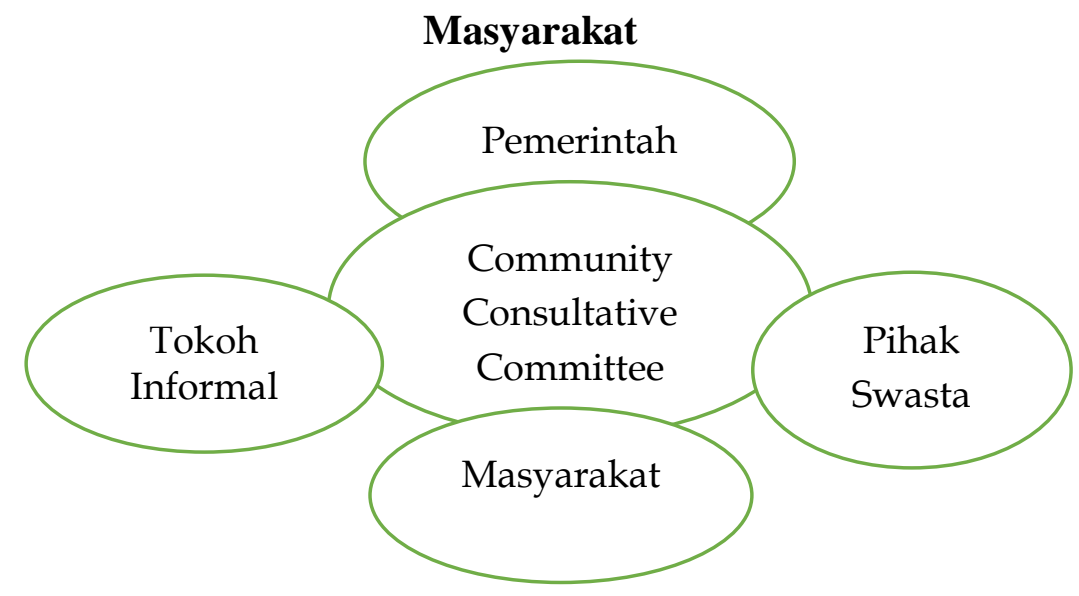

Sumber: Dumasari, 2014

Ilustrasi Gambar 2 menunjukkan adanya keterlibatan dan kontribusi semua pemangku terkait seperti pemerintah, swasta, organisasi non pemerintahan 
(LSM) dan masyarakat menjadi penting dalam proses pembangunan dan pengembangan masyarakat desa. Tiap-tiap komponen kelembagaan (lazim disebut dengan stakeholder) tersebut memiliki peran dan fungsi sendiri yang karena itu perlu diatur dan disepakati sehingga menjadi upaya sinergis yang saling menguatkan antara satu dengan lainnya. Keberfungsian dari jejaring antar kelembagaan tersebut dapat menunjukkan tingkatan interaksi yang menunjukkan komitmen, keterlibatan dan tingkat ikatan yang hendak dibangun antar mitra jejaring (Dumasari dalam Puspitasari, 2016).

Usaha merawat jejaring kelembagaan pemuda desa ini penting karena adanya kebutuhan antar individu (pemuda) sebagai upaya untuk fokus pada sumber daya yang dimiliki, namun sekaligus dapat mengakses kesempatan lain yang tidak mungkin terpenuhi jika diakses sendiri secara langsung. Keberadaan dari jaringan ini setidaknya mampu menjembatani antar aktor untuk menciptakan solusi-solusi jangka pendek bahkan dalam banyak hal strategis atas suatu persoalan tertentu. Kombinasi beragam dari sumber daya yang dimiliki sebuah jaringan secara efektif juga akan mampu memberi pengaruh pada kelompok/komunitas di luar jaringan. Pengaruh pada akhirnya akan memberi perluasan pemahaman atas isu perjuangan yang diusung dalam jaringan.

Bila dikaitkan dengan konsep jaringan, koordinasi menjadi kata kunci untuk menjelaskan bahwa organisasi dikelola oleh aktor-aktor yang setara (horisontalisasi aktor), bukan dalam kerangka kerja top-down. Kondisi ini yang diupayakan oleh penggerak kewirausahaan desa (wirausaha muda) untuk membangun dan merawat jejaring. Berikut ini adalah elemen pembangun dan perawat jejaring (network building and maintaining):

Tabel 1. Elemen Pembangun dan Perawat Jejaring

\begin{tabular}{|l|l|}
\multicolumn{1}{|c|}{ ELEMEN PEMBANGUN } & \multicolumn{1}{c|}{$\begin{array}{c}\text { ELEMEN UNTUK } \\
\text { JEJARING }\end{array}$} \\
\hline $\begin{array}{l}\text { MEMPERTAHANKAN DAN } \\
\text { MERAWAT JEJARING }\end{array}$ \\
\hline $\begin{array}{l}\text { Masing-masing anggota mempunyai } \\
\text { komitmen }\end{array}$ & Adanya kesepakatan norma yang jelas \\
\hline $\begin{array}{l}\text { Ada misi dan agenda bersama yang } \\
\text { jelas }\end{array}$ & Organisasi yang longgar \\
\hline Adanya visi dan identitas bersama & Adanya kepemimpinan bersama \\
\hline $\begin{array}{l}\text { Pendefinisian peran dan fungsi sesuai } \\
\text { dengan potensi dan karakter aktor }\end{array}$ & Kepercayaan (trust) \\
\hline $\begin{array}{l}\text { Pendefinisian aturan main dan proses } \\
\text { pengambilan keputusan }\end{array}$ & Partisipasi yang luas di antara anggota \\
\hline $\begin{array}{l}\text { Pengidentifikasian skill dan } \\
\text { sumberdaya yang dimiliki anggota }\end{array}$ & Sharing agenda dan informasi \\
\hline
\end{tabular}

(Sumber: Puspitasari, 2012 dalam Modul Kepemimpinan Pemuda). 
Satu hal yang mesti dipahami, jejaring bukanlah sesuatu yang hadir dengan sendirinya secara alamiah. Jejaring melibatkan proses aktif nan dinamis, termasuk juga konflik dan negosiasi baik secara internal maupun dengan aktor eksternal yang menjadi target perubahan. Oleh karena itu, jejaring memerlukan adanya komitmen aktif untuk melakukan pembelajaran (lessons drawing) agar dinamika serta konflik dapat dikelola (Pamungkas dalam Puspitasari, 2012). Atas dasar itulah, diperlukan adanya kemampuan untuk membangun dan merawat jejaring yang ada.

Belajar dari pengalaman kedua wirausaha muda desa tersebut, masingmasing memiliki kemampuan dalam menginisiasi jejaring dengan para pihak sekaligus melakukan aktivitas kolaboratif yang mendukung proses pencapaian tujuan kegiatan ekonomi dalam rangka menjawab problem sosial desa. Kedua wirausaha muda desa ini mampu merawat relasi dengan para pihak yang dimulai dengan memastikan ikatan nilai kerjasama, sinergi dan partisipasi di internal organisasi/kelembagaan/komunitas lokal desa. Kondisi ini menjadi basis gerakan kedua wirausaha muda untuk kemudian memperoleh dukungan dari pihak pengambil kebijakan di daerah dan perusahaan (swasta). Secara jangka panjang memunculkan kekuatan strategis bagi kedua wirausaha muda desa ini untuk membangun kerjasama/kemitraan ekonomi bisnis sehingga berdampak pada kemajuan dan perkembangan usaha rintisan mereka. Dalam proses bermitra strategis tersebut tidak lepas dari kapasitas kepemimpinan mereka melalui cara-cara kreatif dan inovatif. Keteladanan menjadi bagian dari realisasi nilai kepemimpinan dengan caracara yang baik, membangun kerjasama serta saling menghormati. Dengan demikian, masing-masing pihak dapat tumbuh, maju dan berkembang bersama dalam mewujudkan usaha pembangunan desa sejahtera berkelanjutan.

\section{KESIMPULAN}

Pembangunan desa merupakan salah satu bentuk investasi negara baik berupa kebijakan maupun pendanaan ini memiliki sederet tujuan mulia yaitu untuk mendistribusikan layanan sosial bagi masyarakat, menanggulangi kemiskinan, meningkatkan kualitas hidup dan penghidupan sumber daya manusia, membuka kesempatan kerja yang berujung pada kesejahteraan masyarakat desa. Beragam tantangan dan peluang muncul mengiringi cita dan harapan tersebut yang perlu dijawab oleh seluruh elemen masyarakat desa mulai dari aparatur desa, kelembagaan desa sampai dengan pemuda. Peranan dari semua unsur lokal masyarakat desa dalam mengelola potensi dan aset desa sebenarnya juga bertujuan untuk meningkatkan kapasitas mereka guna mencapai peranannya yang lebih baik. Pengalaman kedua pemuda penggerak desa (wirausaha muda desa) menjadi penting khususnya untuk memobilisasi potensi dan aset desa dengan upaya-upaya serius dalam pelibatan elemen masyarakat desa. Dengan demikian tidak terjadi kondisi stagnasi produktivitas desa yaitu desa dapat tumbuh seiring dengan adanya pasokan-pasokan input pendapatan bagi desa karena adanya optimalisasi pemanfaatan sumber daya lokal desa.

Pengembangan kewirausahaan desa yang salah satunya dimotori oleh unsur pemuda ini menjadi 'daya ungkit' untuk membangkitkan spirit kolektif warga desa dalam proses penciptaan nilai tambah di kawasan perdesaan oleh masyarakat 
sendiri. Penguatan kapasitas pemuda dan masyarakat menjadi bagian penting yang dilakukan oleh pemuda dan diupayakan terbentuk secara keberlanjutan dengan tidak menciptakan ketergantungan baru kepada berbagai pihak. Dengan kata lain, pengembangan kapasitas tersebut tumbuh secara mandiri di masyarakat sehingga mendorong terjadinya proses pembelajaran secara sosial (social learning). Dalam penjelasan Rustiadi dan Sugimin (2007) yaitu social learning dapat terjadi ketika institusi dalam suatu wilayah perdesaan mampu meningkatkan kemampuannya dalam mengatasi masalah yang dihadapi. Dalam praktek di kedua wilayah kajian menunjukkan bahwa pemuda menjadi inisiator sekaligus pelaku bahkan menjadi teladan untuk membangun kekuatan sosial masyarakat dalam membangun desa.

Para wirausaha muda ini muncul dari lingkungan sosial (context) desa yang memiliki permasalahan sosial berupa kemiskinan maupun pengangguran. Dengan bekal spirit kewirausahaan, mereka mampu melakukan pencarian dan pengimplementasian peluang bisnis sesuai sumber daya yang ada di desa dengan orientasi pemecahan masalah sosial desa. Keterlibatan mereka dalam pembangunan desa menunjukkan bentuk partisipasi riil yang berkesinambungan sebagai hasil proses interaksi antara kegiatan bisnis dan pengorganisasian masyarakat dengan menunjukkan orientasi budaya modern, kreatif dan inovatif. Tentunya hal ini menjadi inspirasi bagi pemuda desa lainnya agar berkontribusi bagi desa tanpa harus meninggalkan desa melainkan membangun strategi kreatif dan inovatif untuk menumbuhkan gerakan ekonomi berkelanjutan di desa. Secara jangka panjang, bentuk kontribusi para wirausaha muda desa ini dapat memberikan kesejahteraan berkelanjutan bagi masyarakat perdesaan baik di level lokal (daerah) maupun nasional.

\section{DAFTAR PUSTAKA}

Rahardjo. 2004. Pengantar Sosiologi Pedesaan dan Pertanian. Yogyakarta: Gadjah Mada University Press.

Hillyard, Sam. 2007. The Sociology of Rural Life.UnitedKingdom: Berg Publisher.

Rustiadi, Ernan dan Sugimin Pranoto.2007.Agropolitan:

Membangun Ekonomi

Perdesaan.Bogor: Crestpent Press.

Rukminto Adi, Isbandi.2008.Intervensi Komunitas: Pengembangan Masyarakat Sebagai Upaya Pemberdayaan Masyarakat. Jakarta: PT Grafindo Persada.

Puspitasari, Dewi Cahyani. 2012. Pengorganisasian dan Pengembangan Jaringan Untuk Advokasi Kebijakan dalam Modul Kepemimpinan Pemuda, Kerjasama Kemenpora-Youth Studies Centre (You Sure), FISIPOL,UGM.

Kartika, Ray Septianis. 2013. Peluang Mengembangkan Kewirausahaan

Desa Berbasis Potensi Desa (Studi Deskriptif di Desa Karang Rejo,

Kecamatan Negeri

Katon,Kabupaten

Pesawaran,Kampung Suka Jawa, Kecamatan Bumi Ratu, Kabupaten

Lampung Tengah dan Desa

Sidoasri, Kecamatan Candi Puro, Kabupaten Lampung Selatan,Propinsi Lampung).

Artikel jurnal binapraja, 10

November 2013, diunduh dari www.binaprajajournal.com.

Agusta, Ivanovich dan Fujiartanto (ed).2014.Indeks Kemandirian 
Desa: Metode,Hasil dan Alokasi Program Pembangunan.Jakarta: Departemen Sains Komunikasi dan Pengembangan Masyarakat, Fakultas Ekologi Manusia, IPB dengan Yayasan Pustaka Obor Indonesia.

Dumasari. 2014. Dinamika Pengembangan Masyarakat

Partisipatif.Yogyakarta: Pustaka Pelajar.

Kuratko, Donald. 2014. Introduction to Entrepeneurship.Canada: SouthWestern Cengage-Learning.

Suharto, Didik. 2016. Membangun Kemandirian Desa (Perbandingan UU No.5/1979, UU No.22/1999, \&UU No.32/2004 serta Perspektif $U U$ No.6/2014). Yogyakarta: Pustaka Pelajar.

Iqbal, Mhd dan Ilham. 2016. Membangun Desa,Membangun Indonesia:Seri Buku: Diskusi Online Indonesia.Surabaya: Pustaka Saga.

Asy'arie, Musa. 2016. Filsafat Kewirausahaan dan Implementasinya: Negara dan Individu. Yogyakarta: Lembaga Studi Filsafat Islam (LESFI).

Damsar dan Indrayani.2016.Pengantar Sosiologi Perdesaan. Jakarta: Kencana.

Zid, Muhamad dan Ahmad Tarmiji Alkhudri.2016. Sosiologi Pedesaan: Teorisasi dan Perkembangan Kajian Pedesaan di Indonesia.Jakarta:Raja Grafindo Persada.

Puspitasari, Dewi Cahyani. 2016.

Wirausaha Sosial Muda Desa: Peran Strategis Pemberdayaan Masyarakat Desa.Makalah Seminar Nasional Universitas Negeri
Lampug (UNILA), Lampung, 12 November 2016.

Aulia, Nur Agis. 2014. Kunci Pemberdayaan Masyarakat adalah Berkelompok.diunduh melaluiwww.inilah.com bulan Desember 2016.

Dokumentasi sejarah pengelolaan Nglanggeran diakses melalui www.gunungapipurba.com pada bulan September 2016.

Komunitas Banten Bangun Desa (BBD) diunduh dari http://bantenbangundesa.blogspot.c o.id/, November 2016.

Radius, Dwi Bayu. 2016. Petani yang Merdeka diunduh dari http://print.kompas.com/baca/sosok /2016/08/18/Petani-yang-Merdeka, Desember 2016. 